\title{
Differences of Pathophysiology in Experimental Meningitis Caused by Three Strains of Streptococcus Pneumoniae
}

\author{
Martin G. Täuber, Margaret Burroughs, \\ U. Marcus Niemöller, Herbert Kuster, \\ Urs Borschberg, and Elaine Tuomanen
}

Medical Service, San Francisco General Hospital, San Francisco,
California; Rockefeller University, New York City; Department of
Medicine, University Hospital, Zürich, Switzerland

Differences in cytochemical and pathophysiologic abnormalities in experimental meningitis caused by pneumococcal strains $A, B$, and $C$ were determined. Strain $C$ produced the most severe abnormalities of cerebrospinal fluid (CSF) concentrations of lactate $(P<.01)$, protein $(P$ $<.02)$, and glucose $(P<.01)$, CSF white blood cell count $(P<.04)$, cerebral blood flow $(P<$ $.02)$, and clinical signs $(P<.05)$. Brain edema occurred only with strains $A$ and $C$, with no association with disease severity; intracranial hypertension was also independent of disease severity. Strain B, not $C$, achieved the highest bacterial titers in the CSF $(P<.005)$. The widely different abilities of strains of Streptococcus pneumoniae to induce intracranial abnormalities suggest that virulence determinants affect not only evasion of defense during colonization and invasion, as shown in other models, but also determine the course of disease once infection has been established. Differences of cell-wall metabolism among pneumococcal strains may play a role in this latter phase of the development of meningitis.

Bacterial meningitis causes death and neurologic sequelae in a large proportion of patients affected [1-4] by mechanisms that are currently not well understood [5]. Pathophysiologic alterations that may contribute to injury to the central nervous system include disruption of the integrity of the blood-brain barrier [6,7], altered cerebrospinal fluid (CSF) hydrodynamics [8], increased intracranial pressure [9-11], the development of brain edema $[9,10]$, changes of cerebral metabolism $[12$, 13], and alterations of cerebral blood flow [12-16].

Pneumococcal meningitis has a higher mortality rate than that caused by either Neisseria meningitidis or Haemophilus influenzae, the two other important meningeal pathogens [3, 17]. Only a minority of the 84 serotypes of Streptococcus pneumoniae frequently cause invasive disease in humans [18]. This selectivity may be related to differences in the ability of different serotypes to colonize and invade the host, but once infection is established the overall clinical significance of a strain is also the result of its ability to induce severe disease. Little is known about these latter aspects of virulence in pneumococcal meningitis.

In the present study we examined pathophysiologic altera-

Received 2 July 1990; revised 1 October 1990.

Presented in part: 27th Interscience Conference on Antimicrobial Agents and Chemotherapy, September 1988, Los Angeles (abstract 880).

Grant support: Swiss National Foundation for Scientific Research (3.858.0.86) and Ciba-Geigy, Basel, Switzerland (to M.G.T.); National Institutes of Health (AI-16794 to E.T.).

Reprints or correspondence: Dr. Martin G. Täuber, Microbial Pathogenesis Unit, Box 0811, San Francisco General Hospital, 1001 Potrero Ave., San Francisco, CA 94110.

The Journal of Infectious Diseases 1991;163:806-811 (C) 1991 by The University of Chicago. All rights reserved. 0022-1899/91/6304-0021501.00 tions of meningitis induced by three pneumococcal strains. We used a model of meningitis in which the infecting pathogen is directly inoculated into the CSF [19] to test the hypothesis that strain-specific microbial factors operative once the pathogen has reached the subarachnoid space are important determinants of disease severity.

\section{Materials and Methods}

Characterization of bacterial strains. Three encapsulated strains of $S$. pneumoniae isolated from patients with meningitis were used in the study. The capsular types of the three strains were 3,1 , and 9 for strains A, B, and C, respectively (strains B and C were a gift from O. Zak, Ciba-Geigy, Basel, Switzerland). Strain A produced very large, mucoid colonies on blood-agar plates, while the two other strains grew to much smaller, smooth colonies. Capsular expression was stable in vitro and after passage through rabbits. In vitro doubling times in Todd-Hewitt broth were $27 \mathrm{~min}$ for strain A and 33 min for strains B and C. Spontaneous release of teichoicated cellwall material in vitro was estimated by prelabeling the teichoic acid and lipoteichoic acid of the pneumococcal cell surfaces with $1 \mu \mathrm{Ci}$ / $\mathrm{ml}\left[{ }^{3} \mathrm{H}\right]$ choline (Amersham Radiochemicals, Arlington Heights, IL) for $6 \mathrm{~h}$, growing the strains in unlabeled medium for $2 \mathrm{~h}$, and then measuring $\left[{ }^{3} \mathrm{H}\right]$ choline in cell wall precipitated in boiling SDS [20]. During logarithmic growth in a semisynthetic medium, $\mathrm{C}+\mathrm{y}$ [20], release of $\left[{ }^{3} \mathrm{H}\right]$ choline was on the order of only $4 \%-5 \%$ per generation for strains $B$ and $C$, while strain $A$ lost $12 \%$ per generation. In the stationary phase, spontaneous release of cell wall was significantly less for strain B ( $51 \%$ over $12 \mathrm{~h}$ ) compared with C (78\%) or A $(94 \%)$. All strains were sensitive to penicillin (MIC $\leqslant 0.03$ $\mathrm{mg} / \mathrm{l})$. Strains $\mathrm{A}$ and $\mathrm{B}$ exhibited a classic lysis-sensitive response to penicillin (>60\% reduction in turbidity at $4 \mathrm{~h}$ ), while the response of strain $\mathrm{C}$ to penicillin paralleled that of a lysis-defective strain lyt $4-4(<20 \%$ reduction of turbidity at $4 \mathrm{~h}$ ) [20].

To produce the inoculum for the animal studies, the organisms 
were grown on blood-agar plates, resuspended in $0.9 \% \mathrm{NaCl}$, and stored at $-70^{\circ} \mathrm{C}$. To infect the rabbits, the thawed inoculum was grown in Todd-Hewitt broth for $6 \mathrm{~h}$, washed, and suspended in $0.9 \% \mathrm{NaCl}$.

Preparation of cell-wall extracts. Pneumococcal cell-surface components were prepared according to methods described previously [21]. Intact cell wall was purified as described for preparation A, peptidoglycan free of teichoic acid was prepared as in preparation $\mathrm{C}$, and cell-wall fragments generated during penicillin-induced lysis (amidase products) were made as in preparation F. Each component was compared for activity on a weight basis when injected intracisternally.

Model of experimental meningitis. The model of experimental meningitis in rabbits, originally described by Dacey and Sande [19], was modified to allow the study of pathophysiologic parameters [9, 22]. New Zealand white rabbits weighing 2-3 kg were anesthetized intravenously with $30 \mathrm{mg}$ of pentobarbitol $/ \mathrm{kg}$ (Nembutal; Abbott, Cham, Switzerland) and a helmet formed with dental acrylic was attached to the skull by four screws. The animals were then returned to their cages for 3 days. On the day of the experiment, the anesthetized animals were placed in a stereotactic frame (courtesy of $O$. $\mathrm{Zak}$ ) designed to puncture the cisterna magna with a 3.5-inch (8.9$\mathrm{cm}$ )/25-gauge spinal needle (Becton Dickinson, St. Augustine, Spain). After puncture of the cisterna, $0.5 \mathrm{ml}$ of CSF was removed. To induce meningitis caused by live organisms, an inoculum of 0.5 $\mathrm{ml}$ was injected into the cisterna magna. Four animals and two of the three experimental strains were studied on the same day, and animals were randomly assigned to one of the infecting strains (3) or saline control (1). The inoculum was $0.7-1.5 \times 10^{7}$ cfu for strain A, $3.5 \times 10^{4}-2 \times .10^{5} \mathrm{cfu}$ for strain $\mathrm{B}$, and $2 \times 10^{4}-2.5 \times 10^{5}$ cfu for strain $C$. To induce sterile meningitis caused by cell walls, cell-wall preparations suspended in $0.5 \mathrm{ml}$ were injected at $0 \mathrm{~h}$ and $4 \mathrm{~h}$.

After induction of meningitis, the animals were allowed to wake up and returned to their cage. Animals were anesthetized again $24 \mathrm{~h}$ after the first injection when infected with live organisms and $8 \mathrm{~h}$ after the first injection when meningitis was induced by cell walls. The cisterna magna was punctured and $0.5 \mathrm{ml}$ of CSF was removed. An equal amount of $0.9 \% \mathrm{NaCl}$ was replaced through the spinal needle. The spinal needle was removed, and an intraarterial line was placed in one femoral artery in the infected groups.

Experimental parameters. Bacterial titers, white blood cell (WBC) counts, and CSF concentrations of lactate, glucose, and protein were determined by routine methods as described previously $[9,22]$. Intracranial pressure was recorded from the spinal needle placed in the cisterna magna, using a pressure transducer and polygraph as described previously $[9,22]$. Pressures were identical when measured before removal or after replacement of CSF by the same volume of saline. Brain water content (brain edema) was determined as wet-to-dry-weight ratio of one hemisphere and two 100-mg samples of gray matter of the opposite hemisphere and was expressed as grams of water per 100 grams of dry weight $[9,22]$.

Cerebral blood flow was determined by using a modified $\left[{ }^{14} \mathrm{C}\right]$ iodoantipyrine method [23-25]. Before the blood-flow measurement, blood pressure was recorded from the intraarterial line using a pressure transducer (Gould Statham model P32ID; Gould, Oxnard, CA) and a multichannel polygraph (Gilson Medical Electronics, Middleton, WI). Arterial blood gases were measured at this time on an automatic blood gas analyzer (AVL 940; AVL, Graz, Austria). To determine cerebral blood flow, $\left[{ }^{14} \mathrm{C}\right]$ iodoantipyrine $(20 \mu \mathrm{Ci}$; Amersham International, Amersham, UK) in $0.5 \mathrm{ml}$ of $0.9 \% \mathrm{NaCl}$ was injected into a peripheral ear vein. During the next $50 \mathrm{~s}, 15$ timed blood samples were collected from the free-flowing arterial line into preweighed glass vials. Immediately thereafter, animals were decapitated and the brain was removed from the skull. One sample of cortical gray matter from the right parietal lobe, one from the right occipital lobe, and one of the periventricular white matter were collected. All samples weighed $\sim 100 \mathrm{mg}$. The samples were solubilized in $1 \mathrm{ml} \mathrm{(50 \% /50 \% )} \mathrm{of} \mathrm{isopropyl} \mathrm{alcohol/soluene} 350$ (Packard Instruments B.V., Groningen, Netherlands) [25]; $10 \mathrm{ml}$ of hionic fluor (Packard Instruments B.V.) was then added, and ${ }^{14} \mathrm{C}$ counts were determined in a liquid scintillation counter (Packard Tri-Carb Liquid Scintillation Spectrometer; Packard Instruments, Downers Grove, IL). Cerebral blood flow was calculated according to the equation developed by Kety [26]. Since there was no systematic difference between the two cortical samples, the mean of these values is given.

Statistical analysis. Data are presented as mean \pm SD. For each end point, with the exception of WBC counts, equality between the experimental groups was tested by analysis of variance. If significant differences between experimental groups $(P<.05)$ were found, they were further evaluated by Student's $t$ test corrected for multiple comparisons by the Bonferroni method. In the case of CSF WBC counts, nonparametric tests were used (Kruskal-Wallis followed by MannWhitney rank sum tests) due to nonnormality of the data.

\section{Results}

Pathophysiology of meningitis caused by live pneumococci. At $24 \mathrm{~h}$ after infection, animals infected with strain $\mathrm{C}$ were severely ill (lateral recumbent position in $6 / 12$ animals, hypothermia $\left[<39^{\circ} \mathrm{C}\right.$ in an animal with infected CSF $]$ in $6 / 12$ animals). In contrast, none of 9 animals infected with strain $A$ and 1 of 11 animals infected with strain B showed signs of severe illness $(P<.05$ for $C$ vs. other groups combined).

All infected animals had positive CSF cultures, but there were significant differences in bacterial titers in the CSF, with strain $B$ showing the highest titers, strain $C$ being intermediate, and strain $A$ being the lowest $(P<.005$; table 1$)$. CSF lactate concentrations were also significantly different in the three infected groups (table 1). All infected animals had elevated CSF lactate concentrations compared with controls $(P<.01)$, but lactate concentrations progressively increased from strain A to B to C $(5.5 \pm 2.3$ to $10.8 \pm 2.4$ to $17.0 \pm$ $4.0 \mathrm{mmol} / 1 ; P<.01) . \mathrm{CSF}$ protein concentrations showed a pattern similar to that of lactate, although with less-pronounced differences among the three strains (table 1). CSF glucose levels were comparable with those of controls in the animals infected with strains $A$ and $B$, but were significantly reduced in animals infected with strain $\mathrm{C}(P<.01)$. CSF WBC counts were highest in animals infected with strain $\mathrm{C}(P<$ .04 ), while there was no significant difference between the two other infected groups (table 1). Thus, CSF cytochemical changes showed marked differences among the three experimental groups, with animals infected with $\mathbf{C}$, the strain that caused the most severe clinical signs, also showing the most abnormal CSF cytochemical changes. Of note, the differ- 
ences among the three strains were independent of their respective CSF bacterial titers.

Gray matter brain edema developed in animals infected with strain $A$ and to a similar degree in animals infected with strain C $(P<.01)$ but not in animals infected with B (table 2$)$. Hemispheric water contents showed similar differences among groups, but without achieving significance due to the relatively low numbers of animals and multiple comparisons (table 2). Cerebral blood flow also showed significant differences among the three experimental groups. Cortical blood flow was highest with strain $\mathrm{A}$, lower with $\mathrm{B}$, and lowest with $\mathrm{C}(P$ $<.02$; table 2). Of note, comparison with uninfected controls showed that cortical blood flow was increased with strain $A$ and $B$ (table 2). Flow in the subcortical white matter showed a decrease with infection that gradually progressed from strain A (mildest disease) to strain $C$ (most severe disease; $P<.04$; table 2).
Comparison of intracranial pressure, mean arterial blood pressure, blood $\mathrm{pH}$, and arterial $\mathrm{PCO}_{2}$ revealed the least pronounced differences among the three experimental groups (table 3). Compared with uninfected controls, intracranial pressure was elevated in infected animals $(P<.001)$ but without significant differences among the three experimental groups (table 3). Mean arterial blood pressure was higher with strain B, while the other two groups had pressures similar to uninfected controls. All infected animals hyperventilated compared with uninfected controls $(P<.001$; table 3$)$. Mean arterial $\mathrm{pH}$ was slightly elevated in infected animals $(P<.001$ for strain B vs. uninfected controls; table 3).

Meningitis induced by cell-wall fractions. Pneumococcal cell wall induces CSF inflammation [21,27], and it has been proposed that the amount and composition of cell-wall fractions released from infecting strains could modulate some aspects of meningitis [20]. We therefore examined the abili-

Table 1. Cerebrospinal fluid content determinations in rabbits with experimental pneumococcal meningitis.

\begin{tabular}{|c|c|c|c|c|}
\hline & \multirow[b]{2}{*}{$\begin{array}{c}\text { Control } \\
(n=13)\end{array}$} & \multicolumn{3}{|c|}{ Infecting strain } \\
\hline & & $\begin{array}{c}\mathrm{A} \\
(n=9)\end{array}$ & $\begin{array}{c}\text { B } \\
(n=11)\end{array}$ & $\begin{array}{c}\mathrm{C} \\
(n=12)\end{array}$ \\
\hline Bacterial titer, $\log _{10} \mathrm{cfu} / \mathrm{ml}$ & Sterile & $5.20 \pm 0.76^{*}$ & $8.10 \pm 0.36^{*}$ & $6.91 \pm \dot{0} .89 *$ \\
\hline WBC count per $\mathrm{mm}^{3}$ & $23 \pm 31^{\dagger}$ & $1573 \pm 1051$ & $1293 \pm 1290 \ddagger$ & $5570 \pm 7470^{\ddagger}$ \\
\hline Lactate concentration, $\mathrm{mmol} / 1$ & $1.9 \pm 0.2 \S$ & $5.5 \pm 2.3 \S$ & $10.8 \pm 2.4 \S$ & $17.0 \pm 4.08$ \\
\hline Protein concentration, $\mathrm{g} / \mathrm{l}$ & $0.25 \pm 0.14$ & $0.65 \pm 0.72$ & $1.22 \pm 0.73$ & $3.06 \pm 2.15$ \\
\hline Glucose concentration, $\mathrm{mmol} / 1$ & $4.12 \pm 0.42^{* *}$ & $3.90 \pm 0.57$ & $3.48 \pm 1.35$ & $2.75 \pm 1.22^{* *}$ \\
\hline
\end{tabular}

NOTE. WBC $=$ white blood cells.

${ }^{*} P<.005$ among three strains; $\dagger P<.01$ vs. infected (nonparametric tests); $¥ P<.04$ (nonparametric tests); $\$ P<.01$ (comparing each group to each of the others); $\| P<.01$ vs. other groups; $* * P<.01$.

Table 2. Brain edema and cerebral blood flow in rabbits with experimental pneumococcal meningitis.

\begin{tabular}{|c|c|c|c|c|}
\hline & \multirow[b]{2}{*}{$\begin{array}{c}\text { Control } \\
(n=13)\end{array}$} & \multicolumn{3}{|c|}{ Infecting strain } \\
\hline & & $\begin{array}{c}\mathrm{A} \\
(n=9)\end{array}$ & $\begin{array}{c}\text { B } \\
(n=11)\end{array}$ & $\begin{array}{c}C \\
(n=12)\end{array}$ \\
\hline \multicolumn{5}{|c|}{ Brain edema, $\mathrm{g}$ of $\mathrm{H}_{2} \mathrm{O} / 100 \mathrm{~g}$ of dry weight } \\
\hline Hemisphere & $373.7 \pm 7.6$ & $383.1 \pm 7.5$ & $375.9 \pm 15.8$ & $381.2 \pm 10.3$ \\
\hline Gray matter & $437.9 \pm 10.7$ & $457.7 \pm 8.9 *$ & $445.2 \pm 12.3 \dagger$ & $456.2 \pm 20.4^{*}$ \\
\hline \multicolumn{5}{|c|}{ Blood flow, $\mathrm{ml} / 100 \mathrm{~g} / \mathrm{min}$} \\
\hline Gray matter & $52.8 \pm 5.9$ & $68.9 \pm 6.2 \ddagger$ & $60.8 \pm 8.58$ & $49.4 \pm 11.68$ \\
\hline White matter & $27.6 \pm 7.3 \|$ & $25.9 \pm 2.4 \S$ & $21.7 \pm 4.0^{\|}$ & $19.0 \pm 4.0 \S$ \\
\hline
\end{tabular}

$* P<.01$ vs. control; $\dagger$ not significant vs. control; $\ddagger P<.001$ vs. control and vs. strain $\mathrm{C} ; \stackrel{\$}{\$}<<.02$ : $\| P<.04$.

Table 3. Physiologic factors in rabbits with experimental pneumococcal meningitis.

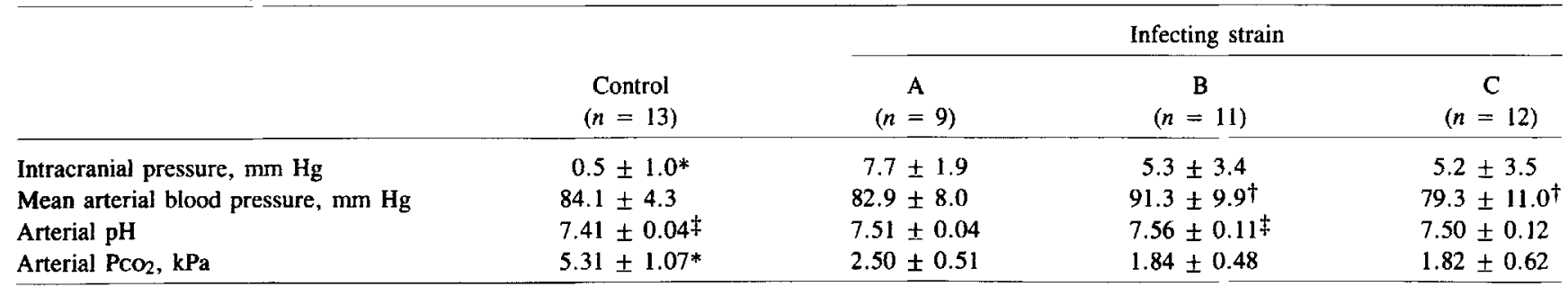

$* P<.001$ vs. other groups; $\dagger P<.01 ;+P<.001$. 
ties of intact and fractionated pneumococcal cell walls to induce pathophysiologic alterations beyond the cytochemical abnormalities in the CSF that have previously been described $[21,27]$. Whole cell-wall $(20 \mu \mathrm{g} \times 2)$ induced abnormalities in all these parameters similar to those seen in true meningeal infection, including increased intracranial pressure (5.0 $\pm 3.8 \mathrm{~mm} \mathrm{Hg}$ ) and brain edema (hemisphere: $385.8 \pm 11.9$ $\mathrm{g}$ of $\mathrm{H}_{2} \mathrm{O} / 100 \mathrm{~g}$ of dry weight). The products of penicillininduced autolysis (amidase products, $5 \mu \mathrm{g}$ ), which consist of teichoicated and nonteichoicated soluble wall fragments [21], also induced significant changes in all examined parameters. The glycan backbone $(15 \mu \mathrm{g} \times 2)$ stripped of teichoic acid, on the other hand, provoked a significantly reduced CSF pleocytosis $(P<.02)$, milder increases in cytochemical changes and intracisternal pressure $(1.4 \pm 1.9 \mathrm{~mm} \mathrm{Hg})$, and no brain edema (hemisphere, $376.3 \pm 6.8 \mathrm{~g}$ of $\mathrm{H}_{2} \mathrm{O} / 100 \mathrm{~g}$ of dry weight). Thus, pneumococcal cell-wall fractions can, depending on their chemical composition, induce pathophysiologic alterations similar to those induced by live organisms.

\section{Discussion}

Traditionally, the age of the patient, the species of the infecting organism, and the time to institution of effective antimicrobial therapy are among the most important variables that determine the clinical presentation and outcome of meningitis. The present experimental study suggests that strain-specific characteristics of pneumococci operative during multiplication of the pathogen in the host may have more pronounced effects on the presentation of the disease than has been recognized. We found that infection with three different pneumococcal isolates resulted in pronounced differences in the pathophysiologic profiles $24 \mathrm{~h}$ after intracisternal inoculation.

Previous clinical and experimental studies of pneumococcal meningitis have shown that high CSF lactate and protein concentrations and low CSF glucose concentrations are associated with severe disease [28-32]. By these criteria the severity of disease was markedly different in the three experimental groups in this study. Animals infected with strain C showed by far the most severe CSF cytochemical changes, which were associated with clinical signs of severe illness in these animals. Clinically, the two other groups could not be distinguished, but CSF lactate concentrations were greater in animals infected with strain $B$ than in animals infected with strain $A$. These differences were paralleled by survival times after infection with the three strains. Animals infected with strain $\mathrm{C}$ had the shortest survival, while it was intermediate with strain B and longest with strain A (data not shown).

Even though brain edema has been consistently documented in several previous studies of experimental meningitis, including studies with pneumococci $[9,22], H$. influenzae $[10]$ and $E$. coli [33], it failed to develop in animals infected with strain $B$, the strain that caused intermediate disease. Furthermore, there was no appreciable difference in the degree of edema between the two other groups, despite their marked difference in disease severity. This suggests that brain edema, as measured in this experimental model, may not always be a direct correlate of the severity of meningitis. The results with pneumococcal cell-wall fragments in the present study suggest that the chemical composition of the fragments, specifically the degree of teichoication, may be important for the induction of brain edema during pneumococcal meningitis. Teichoication appears also to be an important determinant of the inflammatory potential of pneumococcal cell walls [34]. Conceivably, the inability of strain B to induce brain edema could be related to its intrinsically low level of spontaneous cell-wall release. Direct support for this hypothesis awaits the ability to create isogenic mutant strains that differ in their regulation of cell-wall metabolism. That liberation of bacterial products can be important for the development of brain edema during meningitis was shown in experimental $E$. coli meningitis, where the amount of endotoxin released from the infecting pathogen strongly influenced the degree of brain edema [33].

Measurements of cerebral blood flow also provided some results that were unexpected on the basis of previous studies [13-16]. critical blood flow was markedly increased in the least-sick animals infected with strain A. Although blood flow decreased as the disease became more severe, even animals with the most severe disease (strain C) had, on average, cortical blood flows that were not markedly lower than in uninfected controls. Previous studies have suggested that cerebral blood flow is generally reduced in bacterial meningitis [13-15]. No attempt has been made in most of these studies to correlate blood flow changes to the severity of the disease nor to specific characteristics of the infecting pathogen. Our results suggest that mild disease can be associated with increased rather than decreased cortical blood flow and that only severe illness may be associated with reduction of cerebral blood flow to critical levels.

Some pathophysiologic alterations measured in this study lacked the major differences between experimental groups found for CSF cytochemistry and cerebral blood flow. At least for intracranial pressure, the lack of differences may not be too surprising. Several factors, such as altered cerebral blood flow [16], altered CSF hydrodynamics [8], and brain edema [9] can affect intracranial pressure. This makes intracranial hypertension a relatively nonspecific alteration because its different determinants do not necessarily change in parallel, thus potentially neutralizing each other in their effect on intracranial pressure.

Our study does not establish an explanation for the differences in disease caused by the three pneumococcal strains. In contrast to a study of cerebral blood flow in experimental meningitis with a single strain of $H$. influenzae, in which a strong correlation was found between CSF bacterial titers and changes in blood flow [35], the absolute bacterial titers in the CSF obviously did not explain the differences in disease in the present study. Chemical differences among the capsules 
of the strains are also not a likely explanation for the clinical diversity of the disease. The role of the capsule in the virulence of pneumococci is mainly to protect the microorganism from phagocytosis in the absence of capsule-specific antibodies [36, 37]. Previous studies using the same model of meningitis have shown that phagocytosis of pneumococci in the CSF appears to be minimal during the first $24 \mathrm{~h}$ of experimental meningitis [38]. Also, the capsule has been found to almost completely lack inflammatory potential in this model of meningitis [27]. These findings make a major role of the capsule for pathophysiologic variables unlikely.

Our results with the cell-wall fractions and previous studies with similar preparations indicate that the bacterial cell wall could play a role in mediating disease in pneumococcal infections $[20,39,40]$. Similar to endotoxin in the case of gramnegative organisms, cell-wall fragments can induce the release of interleukin-1, and to a lesser extent cachectin, from mononuclear cells [41]. In bacterial meningitis, these cytokines are essential in mediating the inflammatory changes and other pathophysiologic features of the disease, such as the disruption of the blood-brain barrier and the development of brain edema [42-46]. Future studies must examine whether the amount or pattern of cytokine release during meningitis affects the pathophysiologic spectrum of the disease and how characteristics of the infecting microorganism may be related to cytokine release. It is interesting in this context that the most severe abnormalities in the present study were associated with strain $\mathrm{C}$, which abruptly released cell wall in stationary phase. Strain A on the other hand, which readily released cell wall during all growth phases in vitro, caused only mild disease. The relatively low bacterial load of this strain in the CSF could explain the apparent discrepancy between cell-wall turnover and severity of the disease. Differences in CSF bacterial titers achieved by the different strains could result from different susceptibilities of the strains to growth inhibition by high temperature. We have previously shown that growth of strain A is markedly reduced in febrile rabbits [47]. Clearly, more work is needed to characterize differences in cell-wall metabolism among the three strains and to explore the relevance of these differences for the clinical expression of the disease caused by these strains.

Obviously, many bacterial components (e.g., enzymes [48], surface proteins [49]) could be important in modulating the disease caused by a specific strain. In light of the likely complexity of the interaction between microorganisms and host, the role of any putative virulence factor should ideally be defined by studying isogenic strains differing only in this variable. Our observation of the pronounced, strain-specific differences in the pathophysiologic spectrum of experimental pneumococcal meningitis should prompt further efforts to understand these phenomena on a molecular level.

\section{References}

1. Centers for Disease Control. Bacterial meningitis and meningococcemia: United States-1978. MMWR 1979;28:277-9.

2. Feigin RD, Dodge PR. Bacterial meningitis: newer concepts of pathophysiology and neurologic sequelae. Pediatr Clin North Am 1976; 23:541-56.

3. Schlech WF, Ward JI, Band JD, Hightower A, Fraser DW, Broome CV. Bacterial meningitis in the United States, 1978 through 1981. JAMA 1985;253:1749-54.

4. Lebel MH, Freij BJ, Syrogiannopoulos GA, et al. Dexamethasone therapy for bacterial meningitis. Results of two double-blind, placebo-controlled trials. N Engl J Med 1988;319:364-71.

5. Sande MA, Täuber MG, Scheld WM, McCracken GH Jr. Pathophysiology of bacterial meningitis: summary of the workshop. Pediatr Infect Dis J 1989;8:929-33.

6. Quagliarello VJ, Long WJ, Scheld WM. Morphologic alterations of the blood-brain barrier with experimental meningitis in the rat. J Clin Invest 1986;77:1085-95.

7. Kadurugamuwa JL, Hengstler B, Zak O. Cerebrospinal fluid protein profile in experimental pneumococcal meningitis and its alteration by ampicillin and anti-inflammatory agents. J Infect Dis 1988;159:26-34.

8. Scheld WM, Dacey RG, Winn HR, Welsh JE, Jane JA, Sande MA. Cerebrospinal fluid outflow resistance in rabbits with experimental meningitis. J Clin Invest 1980;66:243-53.

9. Täuber MG, Khayam-Bashi H, Sande MA. Effects of ampicillin and corticosteroids on brain water content, CSF pressure and CSF lactate in experimental pneumococcal meningitis. J Infect Dis 1985;151: 528-34.

10. Syrogiannopoulos GA, Olsen KD, Reisch JS, McCracken GH. Dexamethasone in the treatment of experimental Haemophilus influenzae type b meningitis. J Infect Dis 1987;155:213-9.

11. Goitein KJ, Shapiro M, Ramaz M. Intracranial pressure in experimental Streptococcus pneumoniae meningitis in rabbits. In: Miller JD, Teasdale GM, Rowan JO, Galbraith SL, Mendelow AD, eds. Intracranial pressure VI. Berlin: Springer-Verlag 1986:507-11.

12. Paulson OB, Brodersen P, Hansen EL, Kristensen HS. Regional cerebral blood flow, cerebral metabolic rate of oxygen, and cerebrospinal fluid acid-base variables in patients with acute meningitis and with acute encephalitis. Acta Med Scand 1974;196:191-8.

13. Smith AL, Roberts MC, Haas JE, Stull TL, Mendelman PM. Mechanisms of Haemophilus influenzae type b meningitis. In: Sande MA, Smith AL, Root RK, eds. Bacterial meningitis. New York: Churchill Livingstone, 1985:11-21.

14. Goitein KJ, Tamir I. Cerebral perfusion pressure in central nervous system infections of infancy and childhood. J Pediatr 1983;103:40-3.

15. McMenamin JB, Volpe JJ. Bacterial meningitis in infancy: effects of intracranial pressure on cerebral blood flow velocity. Neurology 1984;34:500-4.

16. Tureen JH, Dworkin RJ, Kennedy SL, Sachdeva M, Sande MA. Loss of cerebrovascular autoregulation in experimental meningitis in rabbits. J Clin Invest 1990;85:577-81.

17. Bryan JP, de Silva HR, Tavares A, Rocha H, Scheld WM. Etiology and mortality of bacterial meningitis in northeastern Brazil. Rev Infect Dis 1990;12:128-35.

18. Mufson MA. Streptococcus pneumoniae. In: Mandell GL, Douglas RG, Bennett JE, eds. Principles and practice of infectious diseases. 3rd ed. New York: Churchill Livingstone, 1990:1539-50.

19. Dacey RG, Sande MA. Effect of probenecid on cerebrospinal fluid concentrations of penicillin and cephalosporin derivatives. Antimicrob Agents Chemother 1974;6:437-41.

20. Tuomanen E, Pollack H, Parkinson A, et al. Microbiologic and clinical 
significance of a new property of defective lysis in clinical strains of pneumococci. J Infect Dis 1988;158:36-43.

21. Tuomanen E, Liu H, Hengstler B, Zak O, Tomasz A. The induction of meningeal inflammation by components of the pneumococcal cell wall. J Infect Dis 1985;152:859-68.

22. Täuber MG, Borschberg U, Sande MA. Influence of granulocytes on brain edema, intracranial pressure, and cerebrospinal fluid concentrations of lactate and protein in experimental meningitis. J Infect Dis 1988;157:456-64.

23. Reivich M, Jehle J, Sokoloff L, Kety SS. Measurement of regional cerebral blood flow with antipyrine- ${ }^{14} \mathrm{C}$ in awake cats. J Appl Physiol 1969;27:296-300.

24. Sakurada O, Kennedy C, Jehle J, Brown D, Carbin GL, Sokoloff L. Measurement of local cerebral blood flow with iodo $\left[{ }^{14} \mathrm{C}\right]$ antipyrine. Am J Physiol 1978;234:H59-66.

25. Reid AC, Teasdale GM, McCulloch J. The effects of dexamethasone administration and withdrawal on water permeability across the bloodbrain barrier. Ann Neurol 1985;13:28-31.

26. Kety $S$. Theory of blood-tissue exchange and its application to measurement of blood flow. Methods Med Res 1960;8:223-7.

27. Tuomanen E, Tomasz A, Hengstler B, Zak O. The relative role of bacterial cell wall and capsule in the induction of inflammation in pneumococcal meningitis. J Infect Dis 1985;151:535-40.

28. Baird DR, Whittle HC, Greenwood BM. Mortality from pneumococcal meningitis. Lancet 1976;2:1344-6.

29. Giampaolo C, Scheld WM, Savory J, Sande MA, Wills MR, Boyd JC. A multivariant approach to prognostication in experimental bacterial meningitis. Am J Clin Pathol 1981;76:442-9.

30. Hodges GR, Perkins RL. Acute bacterial meningitis: an analysis of factors influencing prognosis. Am J Med Sci 1975;270:427-40.

31. Tugwell P, Greenwood BM, Warrell DA. Pneumococcal meningitis: a clinical and labơratory study. Q J Med 1976;45:583-601.

32. Weiss W, Figueroa W, Shapiro G, Flippin HF. Prognostic factors in pneumococcal meningitis. Arch Intern Med 1967;120:517-24.

33. Täuber MG, Shibl AM, Hackbarth CJ, Larrick JW, Sande MA. Antibiotic therapy, endotoxin concentrations in cerebrospinal fluid, and brain edema in experimental Escherichia coli meningitis. J Infect Dis 1987;156:456-62.

34. Tomasz A, Saukkonen $K$. The nature of cell wall derived inflammatory components of pneumococci. Pediatr Infect Dis J 1989;8:902-3.

35. Smith AL, Scheifele D, Daum R, Averill D, Syriopolou V. Cerebral blood flow in experimental Haemophilus influenzae meningitis. Pediatr Infect Dis J 1987;6: S1159.

36. Brown EJ, Hosea SW, Hammer CH, Burch CG, Frank MM. A quantitative analysis of the interaction of antipneumococcal antibody and complement in experimental pneumococcal bacteremia. J Clin Invest 1982;69:85-98.
37. Brown EJ, Joiner KA, Cole RM, Berger M. Localization of complement component 3 on Streptococcus pneumoniae: anticapsular antibody causes complement deposition on the pneumococcal capsule. Infect Immun 1983;39:403-9.

38. Emst JD, Decazes JM, Sande MA. Experimental pneumococcal meningitis: mole of leukocytes in pathogenesis. Infect Immun 1983;41:275-9.

39. Tuomanen E, Hengstler B, Rich R, Bray MA, Zak O, Tomasz A. Nonsteroidal anti-inflammatory agents in the therapy for experimental pneumococcal meningitis. J Infect Dis 1987;155:985-90.

40. Ripley-Petyoldt ML, Giebink GS, Juhn SK, Aeppli D, Tomasz A, Tuomanen $E$. The contribution of pneumococcal cell wall to the pathogenesis of experimental otitis media. J Infect Dis 1988;157:245-55.

41. Riesenfeld-Orn I, Wolpe S, Garcia-Busto JF, Hoffman MK, Tuomanen E. The production of interleukin-1 but not tumor necrosis factor by human monocytes stimulated with pneumococcal surface components. Infect Immun 1989;57:1890-3.

42. Mustafa MM, Ramilo O, Olsen KD, et al. Tumor necrosis factor $\alpha$ in mediating experimental Haemophilus influenzae type b meningitis. J Clin Invest 1989;84:1253-9.

43. Saukkonen K, Sande S, Cioffe C, et al. The role of cytokines in the generation of inflammation and tissue damage in experimental gram-positive meningitis. J Exp Med 1990;171:439-48.

44. Mustafa MM, Mertsola J, Ramilo O, Saez-Llorens X, Risser RC, McCracken GH Jr. Increased endotoxin and interleukin $1 \beta$ concentrations in cerebrospinal fluid of infants with coliform meningitis and ventriculitis associated with intraventricular gentamicin therapy. J Infect Dis 1989;160:891-5.

45. Quagliarello VJ, Long WJ, Scheld MW. Human interleukin-1 modulates blood-brain barrier injury in vivo [abstract 614], In: Program and abstracts: 27th Interscience Conference on Antimicrobial Agents and Chemotherapy (New York). Washington, DC: American Society for Microbiology, 1987.

46. Mustafa MM, Ramilo O, Mertsola J, et al. Modulation of inflammation and cachectin activity in relation to treatment of experimental Haemophilus influenzae type b meningitis. J Infect Dis 1989;160:818-25.

47. Small PM, Täuber MG, Hackbarth CJ, Sande MA. Influence of body temperature on bacterial growth rates in experimental pneumococcal meningitis in rabbits. Infect Immun 1986;52:484-7.

48. Paton JC, Lock RA. Hansman DJ. Effect of immunization with pneumolysin on survival time of mice challenged with Streptococcus pneumoniae. Infect Immun 1983;40:548-52.

49. McDaniel LS, Scott G, Kaerney JF, Briles DE. Monoclonal antibodies against protease-sensitive pneumococcal antigens can protect mice from fatal infections with Streptococcus pneumoniae. J Exp Med 1984;160:386-97. 